\title{
Business modelling in farm-based biogas production: towards network-level business models and stakeholder business cases for sustainability
}

\author{
Niklas P.E. Karlsson ${ }^{1} \cdot$ Maya Hoveskog ${ }^{1} \cdot$ Fawzi Halila $^{1} \cdot$ Marie Mattsson $^{1}$
}

Received: 25 October 2017/Accepted: 23 May 2018/Published online: 1 June 2018

(c) The Author(s) 2018

\begin{abstract}
Farm-based biogas production is a promising renewable energy technology with the potential for creating sustainable economic, environmental, and social value. However, Swedish farmers engaged in this activity struggle to turn a profit because of high-investment costs and severe price competition with fossil fuels. One way to address this situation is to reorganize the activity by innovating the business model (BM) towards sustainability. In this study, a team of researchers took an action research approach that proposed solutions for the financial difficulties at a farm cooperative that intended to develop its farm-based biogas production. Two participatory workshops (including researchers, producers, students, and consultants) were conducted using the sustainable business-modelling tool called the Flourishing Business Canvas (FBC). Based on the 215 ideas developed in the workshops, five sustainable BM prototypes were created. These five prototypes form the basis of an approach for initiating the development of a network-level BM for sustainability that highlights its superiority over a single-firm BM. The network-level BM's main advantage in the farm-based biogas context is its strong focus on stakeholder collaboration that supports the development of a stakeholder business case for sustainability. Overall, this study highlights the usefulness of the network concept in the practice of sustainable BM development. Collaborative business modelling for developing network-level BMs that address environmental and social problems for and with stakeholders can be an effective way to increase long-term financial profit and promote the growth of a firm, a network, or an industry.
\end{abstract}

Keywords Business modelling $\cdot$ Stakeholders $\cdot$ Business case $\cdot$ Sustainability $\cdot$ Biogas production

\section{Introduction}

The European Union's research and innovation framework, Horizon 2020, highlights activities aimed at dealing with various societal challenges. These activities relate to renewable energy production, sustainable agriculture, and climate change (European Commission 2011). The renewable energy technology behind farm-based biogas production, under the right conditions, can help to meet these challenges.

Handled by Karel F. Mulder, The Hague University of Applied Science, Netherlands.

Niklas P.E. Karlsson

niklas.karlsson@hh.se

1 School of Business, Engineering and Science, Halmstad University, Kristian IV:s väg 3, 30118 Halmstad, Sweden
Farm-based biogas from organic farm waste can create green energy, develop the circular economy in rural areas, and promote local possibilities for sustainable growth (Boulamanti et al. 2013). Previous research (Bergh 2013; Karlsson et al. 2017) lists the success factors related to Swedish farm-based biogas. However, some farmers engaged in biogas production, such as certain farmers in Sweden, have experienced financial difficulties that hamper the development of the activity (Fallde and Eklund 2015). As Lantz (2013) found in research on biogas production in Sweden, production, distribution, and marketing barriers (e.g., high-investment costs, restricted markets, falling prices, and short-term subsidies) are the primary problems with realizing farm-based biogas production as a profitable business activity. Given these financial difficulties, Swedish farmers may need to change their business models (BM) as they create, deliver, and capture value (Amit and Zott 2012) in the production of biogas. 
There are different ideas about on what a BM actually is. Traditionally, a BM is defined as a conceptual tool that consists of a set of elements and relationships that express a company's logic for earning money (e.g., Osterwalder and Pigneur 2010; Teece 2010). Zott and Amit (2010), who take an activity system perspective, view the BM as a network (i.e., a system of interdependent activities that helps a firm create value by working with its partners). The emerging view is that BMs should take a network-centric perspective rather than a single-firm-centric perspective (Evans et al. 2017). Such network-level BMs may unlock new competences, open new markets, and advance unique value propositions (Lindgren et al. 2010; Palo and Tähtinen 2013).

In line with the network-centric perspective, previous research (e.g., Negro et al. 2007; Negro and Hekkert 2008; Vernay et al. 2013) has addressed the benefits of BM collaboration in farm-based biogas production when networked firms co-create value using shared resources, knowledge, and experience. Such agricultural networks can promote individual farmers' interests as well as the interests of other stakeholders (e.g., suppliers of feedstock and transporters of digestate). In addition, these networks, which can also promote society's sustainability interests, may result in more government support for farmers (e.g., price support) and new ways of using the existing resources, reducing costs, and increasing profit (Amer and Bolwig 2013; Ericsson et al. 2013; Hellström et al. 2015; Martin 2015). To capitalize on these benefits, a change in perspective is needed-from value creation at the singlefirm level to value co-creation at the network level. This change requires development of a network-level BM shared by firms and their stakeholders.

Designing a new or modified activity system and recombining the firm's (and its stakeholders') resources through innovating a BM can be crucial in making radical improvements that enhance the sustainable performance of BMs in which greater environmental and social value is created and economic sustainability is delivered (Stubbs and Cocklin 2008). Consequently, researchers, including Hall and Wagner (2012) and Boons and Lüdeke-Freund (2013), call for more research on the integration of sustainability in firms' BMs. More specifically, the traditional $\mathrm{BM}$ view of value creation for customers and shareholders should shift to a view that supports value creation for and with a broader range of stakeholders, i.e., developing and realizing a stakeholder business case for sustainability (Schaltegger et al. 2017). This need is especially relevant in the farm-based biogas industry where it is necessary to significantly improve long-term financial viability.

To that end, firms may find it advantageous to engage in collaborative business modelling (Karlsson et al. 2018). Business modelling, especially in the sustainability context with its systems perspective, is a complex, collective, and co-creational activity that emphasizes active social participation and interaction (Demil and Lecocq 2015). In collaborative situations, business modelling can lead to new insights and can support the collaborating actors' sustainability policies and practices while simultaneously highlighting strong and weak areas in their BMs.

In summary, addressing the current financial difficulties for the Swedish farm-based biogas industry through simultaneous creation of environmental and social value requires systematic collaboration in an extended network of farmers and their stakeholders. The aim of this study is, therefore, to propose an empirically based approach for the identification and engagement of relevant stakeholders in firms' development of network-level BMs aimed at promoting sustainability and profitability. More specifically, this paper addresses the following research question: How can business modelling initiate the transition towards a network-level BM that can realize farm-based biogas production as a stakeholder business case for sustainability to overcome its financial difficulties? The setting of the study is a Swedish, farm-based biogas cooperative that has encountered difficulties in its early development stage. The cooperative needs help in overcoming these difficulties. The primary data for the study were collected in two ideation workshops.

The rest of the paper is structured as follows. Section "Theoretical background" presents the theoretical background and the relevant concepts for the study. Section "Method" presents the paper's research method. Section "Sigma - the biogas-producing farm cooperative" presents the case on which the research is based. Section "Results" presents the findings from the ideation workshops and the network-level BM approach. Section "Discussion" discusses the results and contributions of this research, including the theoretical and managerial implications and suggestions for future research. Section "Conclusions" presents the conclusions.

\section{Theoretical background}

\section{Network-level business models for sustainability}

A BM can be defined as a unit of analysis that describes firm's activities (Amit and Zott 2001). Others describe the $\mathrm{BM}$ as a holistic concept that presents the various components of a firm's activities that propose, create, deliver, and capture value (Bocken et al. 2014; Chesbrough and Rosenbloom 2002; Demil and Lecocq 2010; Morris et al. 2005; Osterwalder and Pigneur 2010). Osterwalder et al. (2005) describe how the BM concept is commonly used: (1) to interact with suppliers, customers, and partners; and 
(2) to reduce business complexity to a comprehensible level. Therefore, a BM has a set of components that expresses a firm's business logic. Traditionally, a BM focuses on the organization and infrastructure of the firm's supply chain and customer relationships. A traditional BM also takes a single-firm focus as it emphasizes economic value while neglecting environmental and social value (Joyce and Paquin 2016), thus undermining the realization of economic, environmental, and social growth (i.e., sustainability) (Schaltegger et al. 2016a).

With the intention of identifying, forming, and/or acting upon business opportunities, firms establish relationships and collaborative arrangements such as networks (Bessant and Francis 1999). Relationships are often established in a network that produce both tangible and intangible values through dynamic exchanges between two or more individuals, groups, or organizations, whether in the public or the private sector (Allee 2011). Networks are thus commonly used to seek potential partners for collaborative BM development intended to achieve individual and joint goals (Lindgren et al. 2010; Österle et al. 2001) such as sustainable value creation.

The literature shows that firms in networks are more successful in producing sustainable value than stand-alone firms (e.g., Johnson and Suskewicz 2009; Rohrbeck et al. 2013). The main reason for such success is the networked firms' explicit focus on the holistic, stakeholder perspective. This perspective not only benefits customers and firms (shareholders) but also the overall system in which the BM is embedded (Schaltegger et al. 2016a). As a result, the networked BM can enhance value creation and capture aspects of the system more readily than the single-firm BM that supports the traditional (profit-first) definition of corporate success (Lüdeke-Freund and Dembek 2017). Given this perspective, the research on sustainable BMs increasingly takes a network-level approach that embraces the system dynamics perspective on the embeddedness of BMs in society and their relationship to their environments (Rauter et al. 2017; Upward and Jones 2016).

In contrast to the traditional BM, a sustainable BM provides substantial positive and/or significantly reduced negative environmental and social impacts through changes in the way the firm and its value network create, deliver, and capture value, or in the way that they change the value propositions (Bocken et al. 2014). Further, Lüdeke-Freund (2010) points out that, compared to the traditional BM, the sustainable BM advances competitive advantage through producing greater customer value whilst contributing to the long-term development of the firm and providing various benefits to the public and private sectors. A sustainable BM also includes structural and cultural benefits in collaboration with a broad range of stakeholders, all of whom support economic, environmental, and social sustainability for the firm and its surroundings (Stubbs and Cocklin 2008).

Thus, the collaborative view of sustainable BMs extends the single-firm, traditional BM perspective to a networklevel BM perspective (Abdelkafi and Täuscher 2016). The network-level BM, which is open-ended and dynamic, focuses on value co-creation and cost reduction. This focus requires continuing development as the environment (and even the network) changes (Bankvall et al. 2017). According to Palo and Tähtinen (2013), the network-level $\mathrm{BM}$ reflects close cooperation among the networked firms. Interactions, which are the basis of this cooperation, are, therefore, crucial in the creation of the network-level BM (Araujo et al. 2003).

For biogas production, a network-level BM may consist of a group of upstream suppliers (e.g., technical equipment and biological feedstock suppliers), downstream suppliers (e.g., biogas and digestate distributors and retailers), and customers (e.g., municipalities and manufacturing industries) (Huttunen et al. 2014). Competitive advantage and sustainable value creation in biogas production can thus be achieved by developing and supporting a joint networklevel BM that connects network partners' competencies and knowledge and supplements the firms' individual BMs (Lindgren et al. 2010).

However, developing and implementing a network-level $\mathrm{BM}$ is a complex undertaking that requires the assistance of all network actors. They must be prepared to establish relationships, to work with others (Hellström et al. 2015; Möller et al. 2005), and to share a common vision for business development. Network-level BM activities, therefore, require that the network actors understand (and accept) change (Freytag and Clarke 2012). In some instances, acceptance of a network-level BM may mean individual firms lose some control over their individual BMs as they work with the network partners (Zott et al. 2011). Nevertheless, rethinking the firm as a network partner may facilitate the core integration and delivery of sustainable value in the long term (Evans et al. 2017) through close collaboration with stakeholders as they realize the business case for sustainability (Schaltegger et al. 2017).

\section{The business case for sustainability}

In the business case for sustainability, a firm's economic success is realized through, not just with, environmental and social activities (Kreiss et al. 2016; Schaltegger et al. 2012). Schaltegger and Burritt (2015) report that the relation between business cases and sustainability is linked to the firm's ethical foundations and sustainability management activities. These authors differentiate amongst four business cases for sustainability: cases that are reactionary, 
reputational, responsible, or collaborative. The reactionary and reputational business cases deal with sustainability opportunistically in which the main goal is the maximization of (short-term) profit (e.g., as a reaction to increased market demand for sustainability-oriented products/services or as a way to improve firm reputation and brand value to gain business benefits). In contrast, the responsible and collaborative business cases integrate sustainability as a central part of firm management to create conditions for improved organizational operations and long-term business success. Developing joint business cases through close collaboration with stakeholders offers networked firms the opportunity to enhance their social and environmental well-being as well as sustain their financial viability.

Schaltegger et al. (2017) further emphasize the importance of stakeholder involvement in business cases for sustainability. In their stakeholder theory perspective on business cases for sustainability, they propose that a stakeholder business case for sustainability explicitly aims at value creation for and by stakeholders. This goal can be achieved with business activities that effectively respond to a sustainability problem (e.g., climate change) in a way that creates value for stakeholders involved in the problem solution as well as for other stakeholders who are affected by the problem. It is thus important to involve all stakeholders early in the development of business cases for sustainability, so that the potential consequences of the proposed business activities can be identified. Researchers who have studied the collaborative development of the stakeholder business case for sustainability have found that business modelling is an important facilitator of its success (Geissdoerfer et al. 2016; Joyce and Paquin 2016; Karlsson et al. 2018; Schaltegger et al. 2016b).

\section{Business modelling}

Realizing sustainable value co-creation for and with a wide range of partners and stakeholders is a challenging task. However, the use of business modelling has been shown to be effective in managing the task (Geissdoerfer et al. 2016; Joyce and Paquin 2016; Karlsson et al. 2018). Business modelling can be defined as the creative process of experimenting with BM elements in which innovative BMs that create, deliver, and capture value in new ways are identified (Aversa et al. 2015). The primary goal of business modelling for sustainability is to develop a new and sustainable BM that creates, delivers, and captures value that makes sense to all stakeholders (Bocken et al. 2014). Teece (2010) states that business modelling encourages discussions and visualizations related to new value creation/value capture systems at the conceptual level. He also claims that business modelling works particularly well in unpredictable situations.

Because of uncertainties and risks in terms of time and resource limitations in the innovation of BMs, it is commonly recognized that firms hesitate to test new or modified BMs in the real world (Evans et al. 2017). Business modelling provides an inexpensive and low-risk solution to this problem, because it allows researchers and practitioners to acquire stakeholder input on the BM development via the development of $\mathrm{BM}$ prototypes. The prototypes, which promote objective decision-making and strategy formulation, are used for experimentation and visualization of a new and sustainable BM that creates, delivers, and captures value for all stakeholders (Bocken et al. 2014; Seidenstricker et al. 2014). According to Upward and Jones (2016), a visual representation of a sustainable BM prototype uses a common language that is especially effective for promoting effective collaboration and shared understanding of the factors a firm considers in setting its goals.

Rohrbeck et al. (2013) and Bocken et al. (2013) report that business modelling can be facilitated by the use of collaborative business-modelling tools. The two most widely used tools developed to support business modelling by practitioners and researchers are the Business Model Canvas (Osterwalder and Pigneur 2010), and its derivative, the Value Proposition Canvas (Osterwalder et al. 2014), that focuses on the value proposition element (Hanshaw and Osterwalder 2015). However, these tools take a singlefirm perspective and are limited to traditional business modelling that primarily focuses on customer value and profit maximization. As a result, the single dimension (economic value) of the Business Model Canvas and Value Proposition Canvas makes them unsuitable for generating sustainable BMs in which the full stakeholder network (e.g., suppliers, local companies, municipalities, and society) is integrated in a holistic perspective.

Several visual business modelling tools have been designed for use in the development of sustainable BMs and BM prototypes. These tools integrate a firm's economic, environmental, and social concerns taking a network perspective. The Value-Mapping Tool (Bocken et al. 2013), the Triple Layered Business Model Canvas (Joyce and Paquin 2016), and the Flourishing Business Canvas (FBC) (Upward and Jones 2016) are three sustainable business-modelling tools that primarily aim to stimulate idea generation, discussion, and facilitation of a network perspective on BMs and sustainability.

To summarize, our study builds on the following theoretical knowledge. The traditional view of a BM is that it can be used to manage a firm's supply chain and customer relationships and to maximize its profit, often to the detriment of environmental and social interests. While 
sustainability is not normally considered in this traditional business logic, experience has shown that business sustainability and sustainable BMs can contribute to the combined growth of economic, environmental, and social values. The design and implementation of a sustainable $\mathrm{BM}$ and the realization of a stakeholder business case for sustainability require increased cooperation and changes in the way firms and their stakeholders create, deliver, and capture value. Business modelling and BM prototype development can, if facilitated by a sustainable businessmodelling tool, support the shift from value creation at the single-firm level to sustainable value co-creation at the network level via a joint BM shared by firms and their stakeholders. Such network-level BMs have a significant advantage over individual firms' BMs as far as promoting sustainable value creation.

\section{Method}

\section{Research approach}

In this study, we take an inductive approach (Goddard and Melville 2004). Thus, we collected our empirical data without hypotheses and preconceptions on how the study would evolve. This approach increased the possibilities of discovering intriguing and new findings beyond preset knowledge and relationships (Robson and McCartan 2015). Our research followed a trajectory from the particular (i.e., a Swedish farm cooperative; hereafter Sigma) to the general (i.e., other cooperatives and similar organizations).

Research on joint BMs and sustainability in the Swedish farm-based biogas industry is still at an early stage. Therefore, we used qualitative research methods in our study, because the exploration of BMs in this context involves various actors, resources, and activities intertwined in complex and interdependent relationships (Evans et al. 2017). Creswell and Creswell (2017) claim that it is appropriate to conduct qualitative research in dealing with such complexity and with unfolding sequences and stages in relationships and collaborative actions in which in-depth knowledge is required. Use of qualitative research methods allows the researcher to describe how people experience particular events and situations as well as describe the variations and relationships among the actors (Robson and McCartan 2015). In addition, qualitative research allows deep interaction with the subjects of interest and promotes flexibility in the interaction with actors (Rowlands 2005).

In taking the inductive approach and in using qualitative research methods in our study, we expect to increase our knowledge of the collaborative development of the network-level BM and the stakeholder business case for sustainability. Because our research theoretically addresses business modelling for developing a network-level BM for sustainability and finding solutions to the practical issue of low profitability at a biogas-producing farm cooperative, the action research approach is also suitable for our study.

\section{Action research}

In action research, the researcher works in a "community of practice" to solve a social or organizational problem (Shani et al. 2012). According to Shani and Pasmore (1985), action research is a research method that focuses on conducting the research process with those whose life and actions are studied. Action research is research in action rather than research about action. It emphasizes the generation of useful knowledge co-produced in the local context with practitioners (Susman and Evered 1978). As a method for sequencing events and solving problems, action research allows the researcher to simultaneously study a practical problem, propose solutions, and produce scientific knowledge (Shani and Pasmore 1985).

Using action research, we worked closely with representatives from Sigma to initiate and facilitate the development of a network-level BM for sustainability. With a joint network-level BM, the farmers and their stakeholders might benefit from each other's experiences and knowledge, and might co-create value aimed at establishing a profitable biogas production system that contributes to sustainable, regional development. In contrast with retrospective studies often found in BM research, our use of action research facilitates the study of an existing BM and the attempts to modify it or to craft a new one. According to Demil and Lecocq (2015), action research is a rare and promising approach for informing researchers and managers about the difficulties of implementing changes in the existing and prospective BMs as well as limiting the biases of retrospective studies.

In an action research study of a network or cooperative (such as Sigma), researchers use the plurality of experiences and the capacity in the network as a way to enrich the research process (Shani and Pasmore 1985). Therefore, the researchers for this study (with reference to its theoretical framework) and the Sigma representatives (with reference to their BM development problems) jointly planned, implemented, and evaluated the research process with the intention of producing useful results. The goal was to develop a network-level BM for sustainability that addressed Sigma's organizational problems. Therefore, as participants rather than independent observers of the research (Middel et al. 2006), we acquired knowledge of Sigma's social and organizational issues otherwise unavailable had we used the traditional research methods (Coughlan and Coghlan 2002). In addition, Bergold and Thomas (2012) report that our approach enables 
researchers to put familiar routines and forms of interactions aside as they challenge and rethink established interpretations of situations and strategies.

Action research has several research advantages. It focuses on a range of research activities such as planning, theorizing, exploring, and learning. In this research and learning process, the researcher's long-term relationship with studied phenomena offers a promising opportunity for identifying contextually and theoretically well-grounded research findings (Susman and Evered 1978). Moreover, it is unnecessary in an action research study to rely on the second-hand narratives (e.g., questionnaires and surveys) (Coughlan and Coghlan 2002) because of the researcher's proximity to the studied phenomena.

\section{The flourishing business canvas}

The use of the collaborative FBC tool (Fig. 1) in our study facilitated the collection of primary data through the firsthand observation and interaction. The FBC, which is a significant extension of the widely used and purely profitfocused Business Model Canvas, identifies and describes the fundamental characteristics of BMs conceptualized in the context of real-world economic, environmental, and social systems (Elkington and Upward 2016). The FBC components-(1) three contextual systems, (2) four perspectives, and (3) sixteen building blocks-are both necessary and sufficient to describe a sustainable BM. The three contextual systems are the environment (the planet, all life, and all associated processes), society (people as individuals and groups), and the economy (revenues, costs, and profit). The four perspectives are process, people, value, and outcomes. The sixteen building blocks are topics intended to provoke stakeholder questions about a firm's current or future BM. The responses to these sixteen questions are used to describe and design the BM elements for any firm-past, present, or future, irrespective of the firm's goals. Thus, the FBC provides a consistent way for a firm and its stakeholders to capture the results of its business-modelling efforts (Upward and Jones 2016).

The FBC is the only such tool that can provide the required holistic visual expression of a shared understanding of the frame within which the firm and its stakeholders co-create sustainable BMs (Upward and Davies 2018). The use of the FBC contributes to individual and shared learning about integrated business sustainability,

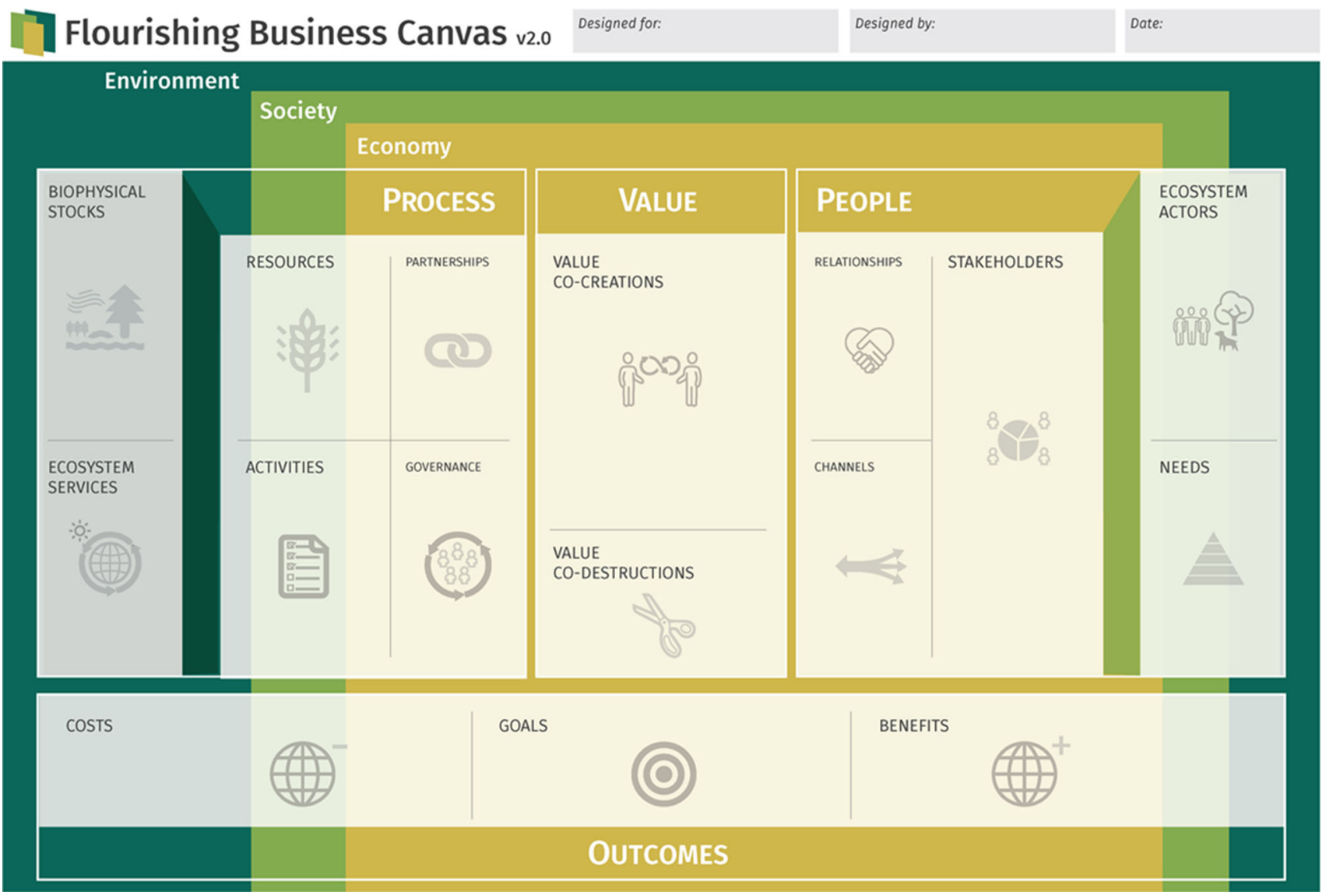

Fig. 1 The flourishing business Canvas v2 (ㄷ Antony Upward/Edward James Consulting Ltd). All rights reserved. http://www. FlourishingBusiness.org. Used with permission 
thereby increasing the possibility that firms and stakeholders co-create outcomes aligned with that knowledge. In so doing, use of the FBC overcomes one of the main weaknesses of the Business Model Canvas and Value Proposition Canvas tools: the neglect of the networked nature of value co-creation and the importance of all stakeholders' interests (Äyväri and Jyrämä 2017). The FBC can thus create consensus amongst a group of people who are working together by motivating them to engage in broader and deeper conversations about the topic at hand, furthering creativity and innovation.

Upward and Davies (2018) report three main advantages of the FBC compared to other business-modelling tools. First, using questions, the FBC systematically helps the actors to learn about every aspect of a sustainable BMboth existing and future-and the connections of the firm to its economic, social, and environmental contexts. These questions are useful for identifying the various risks and opportunities-whether these arise individually from economic, social, or environmental contexts or from some combination of the three. Second, the FBC, which facilitates recording of the responses to the building block questions, offers a consistent way of documenting the business modelling work. These responses are the narrative elements of the BM stories that the firm and its stakeholders think relevant to the firm at present and in the future. Third, once the collective understanding of an existing or future $\mathrm{BM}$ using the consistent structure of the canvas is established, the FBC creates trust among actors, which can facilitate the collaboration on other activities.

\section{Data collection}

Our primary data were collected in March and April of 2016 at a Board of Directors meeting and at two collaborative ideation workshops. We were participants at the board meeting where development issues for Sigma were discussed. We also participated in the workshops attended by Sigma participants (board members and other individuals) and by external participants (university students, researchers, and consultants). All workshop participants worked with the FBC in the formulation of new ideas and possible solutions related to the future development of Sigma's BM.

We took notes on our observations at the board meeting. We audio-recorded the workshops, took more notes, and collected other materials (primarily the FBCs). We also collected secondary data (reports, documents, articles, and website information) that complemented and validated our primary data (Robson and McCartan 2015). Table 1 summarizes our data collection.

\section{Board of Directors meeting}

We introduced ourselves at the Board of Directors meeting and described our study. We presented the BM, the business-modelling concepts, and the FBC tool. We explained how sustainable BM prototypes could be used to develop a network-level BM. We asked questions about Sigma's development plans. Ten board members and two external consultants with specific interests in Sigma attended the $3 \mathrm{~h}$ meeting.

\section{The two ideation workshops}

A workshop can be an effective way to gather a large amount of diverse data on a single occasion (Graham et al. 2015). Therefore, our aim in the two workshops was to collect ideas on how Sigma might develop in the future. We planned and conducted the workshops jointly with a Sigma board member. Together, we evaluated the ideas produced in the workshops. In selecting the workshop participants, we followed Frankenberger et al.'s (2013) advice on the need to select participants capable of out-ofthe-box thinking when generating ideas. The workshops lasted $4 \mathrm{~h}$ each.

The aim of Workshop 1 (March 2016) was to generate ideas for sustainable BM prototypes on how Sigma could overcome its current organizational inertia to develop its biogas activity. The participants were the four researchers, the Sigma board representative, and 41 undergraduate Business Administration students from Halmstad University, Sweden. The researchers were the workshop "facilitators"; the students were the "problem-owners" and "problem-solvers"; the Sigma Board representative was the "knowledge provider" and "utility evaluator". The premise of the workshop was that Sigma required a new and comprehensive network-level BM. The participants, who had no biogas production knowledge, were not constrained by preconceived ideas about biogas production and sale. We wanted to exploit their "outside-the-box thinking" so as to generate novel ideas.

The aim of Workshop 2 (April 2016) was to develop sustainable BM prototypes using the FBC and to evaluate the results from Workshop 1 . The 22 participants were the four researchers, five Sigma Board members (including the Sigma Board representative from Workshop 1), eleven other Sigma members, and two consultants with expertise in biogas development. The researchers were the "facilitators" and "knowledge providers"; the Sigma members and consultants were the "problem-owners", "problemsolvers", and "utility evaluators". We summarized the results from Workshop 1 at the beginning of Workshop 2 . The participants were quite familiar with biogas production in general and with Sigma in particular. 
Table 1 Overview of the data collection

\begin{tabular}{llll}
\hline Data source & Data type & Focus & Used for \\
\hline $\begin{array}{l}\text { Board of } \\
\begin{array}{l}\text { Directors } \\
\text { meeting } \\
\text { Workshops }\end{array}\end{array}$ & Notes & $\begin{array}{c}\text { Reflections on the current business } \\
\text { and organizational situation }\end{array}$ & $\begin{array}{c}\text { Building knowledge on the case and a starting point for } \\
\text { the business model development }\end{array}$ \\
Secondary data & $\begin{array}{c}\text { Websites, documents, articles, } \\
\text { reports }\end{array}$ & $\begin{array}{c}\text { Ideas on business model } \\
\text { development } \\
\text { Acquiring additional knowledge } \\
\text { about Sigma }\end{array}$ & $\begin{array}{c}\text { Developing business model prototypes and a } \\
\text { conceptual network-level business model approach } \\
\text { Complementing and validating primary data }\end{array}$ \\
\hline
\end{tabular}

\section{Data analysis}

The workshops produced 362 ideas related to the sixteen FBC building blocks. A Sigma board member and the researchers eliminated 147 ideas as too broad or repetitive. The 215 remaining ideas were then analyzed and visualized as five sustainable BM prototypes (Figs. 2, 3, 4, 5, 6). These prototypes represent the main findings from the data set. We began our analysis by textualizing our participatory observations, conversations, and experiences. We then analyzed our empirical data-the workshop transcripts and materials, our board meeting notes, and other documents. We looked for repeated patterns such as actions, events, words, or phrases (Robson and McCartan 2015). In analyzing the data, we developed and applied codes (i.e., words or short phrases that represented an overall theme). Assigning the codes, meaningful titles facilitated the identification of patterns that underpin significant concepts (Goddard and Melville 2004) indicated by the ideas. Based on these concepts (e.g., improved marketing and communication and greater profitability through sustainability), we created the five prototypes which are overall representations of the main findings from the data set.

To create a shared understanding of the data as recommended in the action research approach (Shani et al. 2012), at least two researchers were present throughout the entire research process. Their continued presence was useful for the discussions on individual observations and analyses. Moreover, other researchers, who were knowledgeable about the study but were not involved in the data collection, contributed their analyses. Their analyses complemented and validated other researchers' analyses.

\section{Sigma-the biogas-producing farm cooperative}

Sigma, a Swedish agricultural cooperative, is a for-profit entity, owned and operated by its 36 members. Sigma produces farm-based biogas from manure and farm waste. Although Sigma's members work together in the cooperative, they lack a common BM. Thus, to some extent, the members have a single-firm business logic instead of a network-level business logic. In the Sigma case, we investigated how to unify these members in the development of a network-level BM. Sigma was founded following a pilot study that was conducted in 2009 in an agricultural region in the south of Sweden. The pilot study identified farmers' interest in farm-based biogas production in the region where Sigma is located and their willingness to form a cooperative. Of the 36 founding members, 32 are farmers and 4 members are consultants and other interested stakeholders. Initially, 25 farmers planned to construct biogas plants. The raw biogas (55-65\% methane) produced would be upgraded to biomethane (97\% methane) and sold as vehicle fuel.

However, for various reasons, Sigma has not been as successful with the biogas activity as expected. One major reason is the lack of funds for an upgrading facility. This facility is needed to convert raw biogas into biomethane, so it can be injected into the Swedish national gas grid that burns natural gas. Sigma has thus failed to attract large customers such as energy companies and municipalities. Furthermore, biogas electricity must compete with cheaper electricity from other sources. Today, three Sigma members produce biogas for heat and electricity but only for their own use.

Given its lack of economic success, at present, ten Sigma members (including some board members) are working on a new organizational strategy for the cooperative. One plan is to build additional plants that would link to the local gas grid that could then transport the raw biogas to a common upgrading facility. However, this idea is still in the planning stage. Sigma recognizes that more changes are needed to realize this plan. The farmers want to develop their traditional farming activities (their current BMs) by improving the existing biogas production and by developing new business concepts aimed at future biogas expansion. Sigma's main goal for the future is, therefore, to develop a joint network-level BM for sustainability that combines the main farming activities and the expanded farm-based biogas production. 


\section{Results}

\section{Ideas on business model development}

Table 2 presents the 215 ideas related to the sixteen building blocks in the FBC. Three building blocks-goals, benefits, and stakeholders-received the most ideas: 23, 24 , and 21 , respectively.

The 23 ideas in the Goals building block focus on the delivery of economic value to Sigma and social and environmental values to its external stakeholders. To achieve financial profitability, the workshop participants proposed that Sigma create a new company image/brand by identifying new customers and investors, by creating a sales/marketing position, and by developing new and effective ways of communicating with the existing and prospective customers. They proposed that social and environmental values might be achieved with the use of organic and sustainable farming practices and by the promotion of biogas as vehicle fuel.

The 24 ideas in the Benefits building block focus on the acquisition of new skills in sustainable food and energy production, on effective waste management that complements the traditional farming activities, on increased resource efficiency, on sustainability outcomes such as job creation, a reduced environmental impact, and the promotion of renewable energy. Another identified benefit was the knowledge and experience acquired from developing a long-term vision for the integration of biogas production with other farming activities.

The 21 ideas in the Stakeholders building block focus on the collaboration with local authorities, municipalities, banks, other farmers, energy companies, and NGOs (e.g., environmental groups and green associations). Collaboration with these external stakeholders, combined with partnerships with other firms, may result in investment subsidies, access to new customers, and exchanges of skills and experience.

\section{Five sustainable business model prototypes}

The first BM prototype, "marketing and communication" (Fig. 2), mainly focuses on making Sigma more visible through increased marketing activities. Sigma can create a sales/marketing position for the promotion of renewable energy products that are locally produced and that

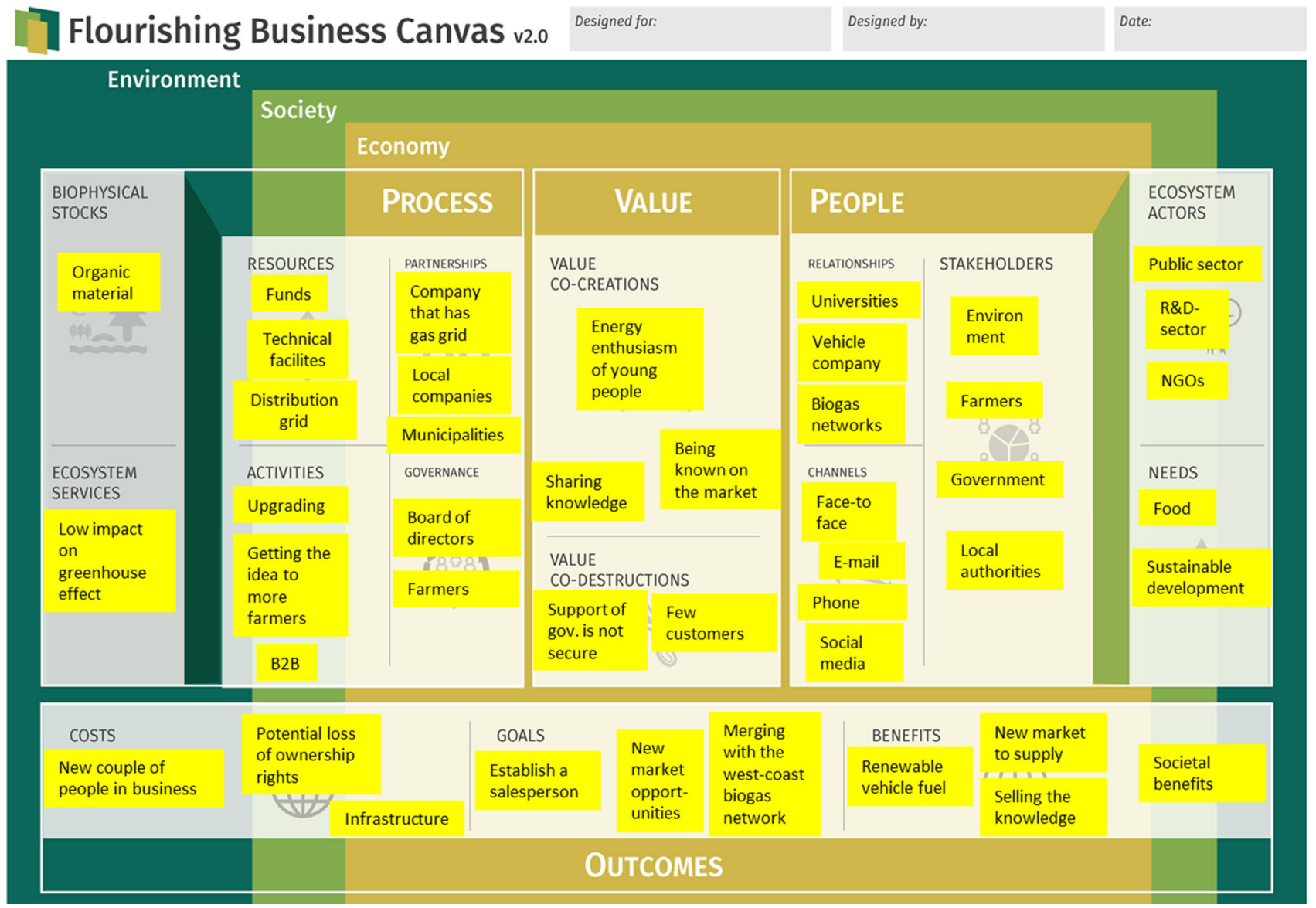

Fig. 2 The "marketing and communication" BM prototype developed in Workshop 1 


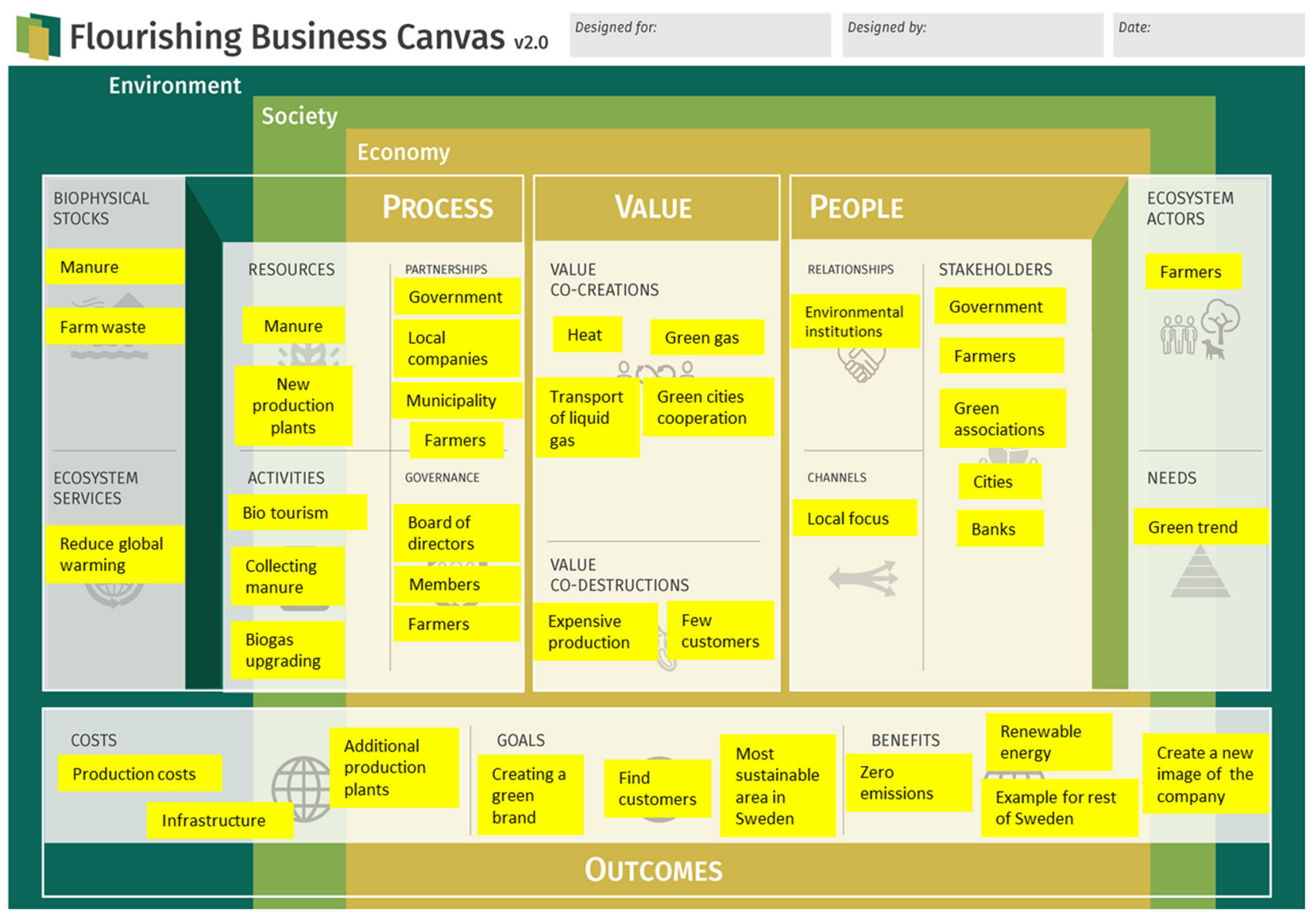

Fig. 3 The "profitability through sustainability" BM prototype developed in Workshop 1

contribute to sustainable development in the region. By expanding its local presence, Sigma can use new marketing strategies to reach more customers and other stakeholders. Platforms such as social media and websites are cost-effective ways to attract public attention and to communicate with existing and prospective customers. In addition, cooperation with municipalities, other farmers, and other biogas producers is also in focus. Cooperation with car manufacturers and dealers can promote the manufacture and sale of biogas-powered vehicles.

The second BM prototype, "profitability through sustainability" (Fig. 3), mainly focuses on brand creation by emphasizing the green trend with its growing demand for sustainable products and services. By creating a strong brand (e.g., "Green Sigma"), Sigma and its geographic region can create an image of an organic and sustainable region that features production and use of farm-based biogas and biofertilizer. In addition, a focus on biotourism in which Sigma offers farm study visits that educate stakeholders and the general public about the biogas concept can lead to more investments and more green customers. Eventually, under a fees arrangement, biotourism might become a profit centre for Sigma. By involving local municipalities and firms as biogas consumers and biogas ambassadors, Sigma may increase its revenue stream as it strengthens its sustainability profile.

The third BM prototype, "local market development" (Fig. 4), focuses on creating the local conditions needed to make biogas production profitable in the long term. To create these conditions, Sigma should cooperate with local actors who would benefit from an association with a farmbased biogas producer. Working with Sigma, such actors can create a local/regional brand that produces and delivers locally and sustainably produced renewable energy. Sigma can also contribute to the local economy as a tourist destination (farm tourism) and as a seller of locally produced products (e.g., meat, vegetables, and organic fertilizer). With the developmental work on the conversion of biogas to liquid fuel and the plan to build another biogas plant, Sigma may increase its local customer segment as well as increase local tax revenues. On a more abstract level, Sigma's cooperation with its local actors can create a regional image of responsible environmental and sustainable development. Success with such an image may lead to greater local financial support from governing bodies. 


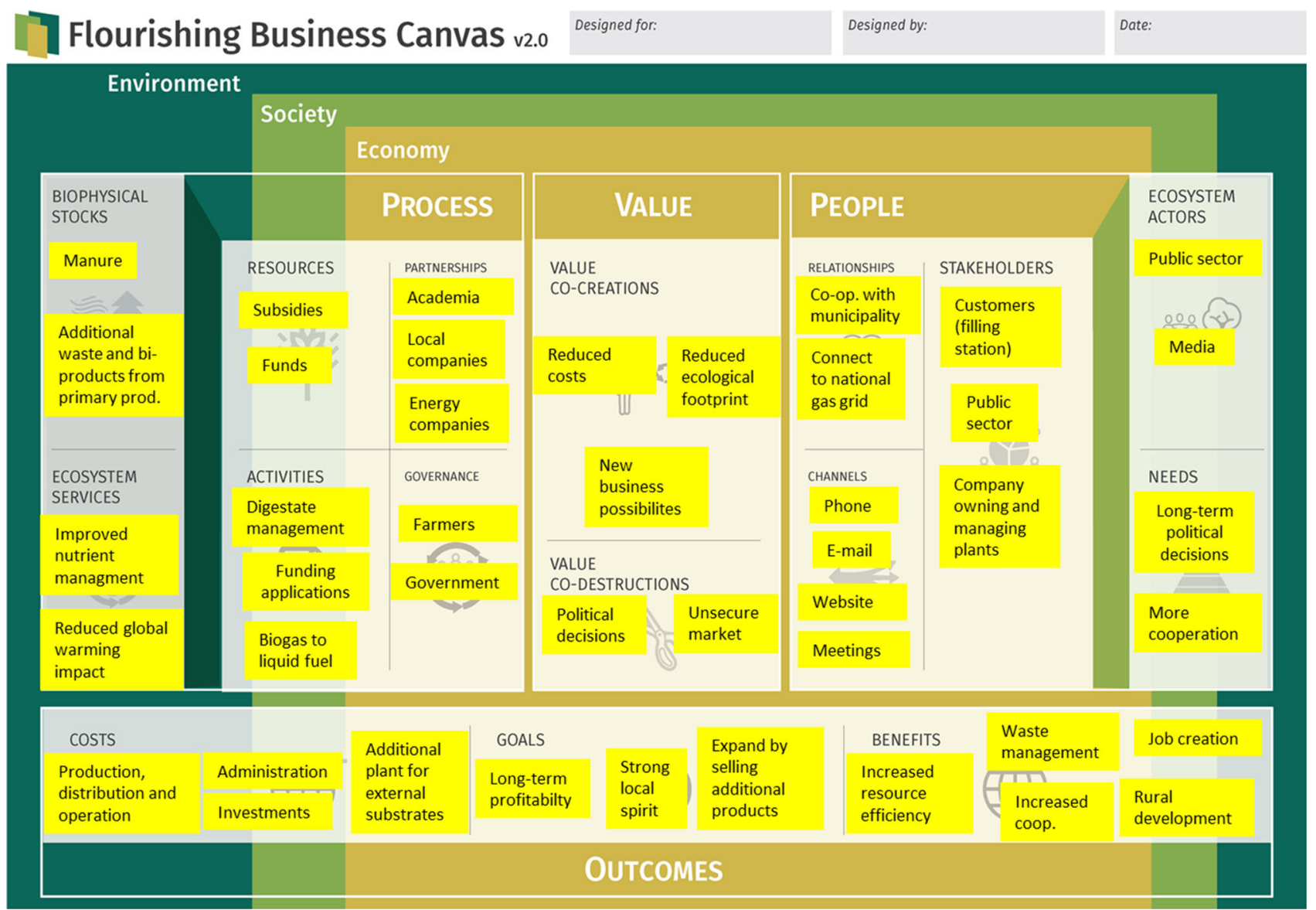

Fig. 4 The "local market development" BM prototype developed in Workshop 2

The fourth BM prototype, "long-distance sales and distribution" (Fig. 5), focuses on the expansion of Sigma's current markets. Sigma may investigate opening a distribution channel to the national gas grid. Or Sigma may look for new customers amongst their established suppliers such as the large dairy company or the agricultural cooperative that sells seeds and fertilizer. Sigma may even look for customers willing to pay a premium for farm-based biogas because of its social benefits (the reduction in greenhouse gases and the increase in rural development and employment).

The fifth BM prototype, "servitization" (Fig. 6), focuses on providing additional customer services and producing locally grown and processed food. One possibility for Sigma is to work with filling stations to promote car washes and automatic refueling and to sell organically grown fruit and vegetables. In the interest of serving the customer and society, Sigma can produce environmental performance reports that focus on the benefits of farmbased biogas. Because environmental regulations are likely to increase, Sigma should position itself in the forefront of this movement. In promoting the service concept, distribution channels that link producers and customers should be prioritized. Moreover, Sigma can develop the servitization concept by working more with veterinarians, dairies, and agricultural equipment repair shops that are outside the network. As tangential service suppliers, they may establish mutually beneficial relationships with Sigma.

\section{The conceptual network-level business model approach}

In this section, we describe the approach for developing a network-level BM for sustainability (Fig. 7) that is based on the five sustainable BM prototypes. First, we present the four network-level BM drivers behind Sigma's motivation to develop the current BM towards a network-level BM. Drivers 2, 3, and 4 are a consequence of driver 1 . The resulting network-level BM is expected to be a significant improvement over the current single-firm BMs of the networked firms. New business opportunities opened up by the network-level BM can promote Sigma's biogas production as an example of a stakeholder business case for sustainability and thereby help solve some of the firms' financial difficulties. 


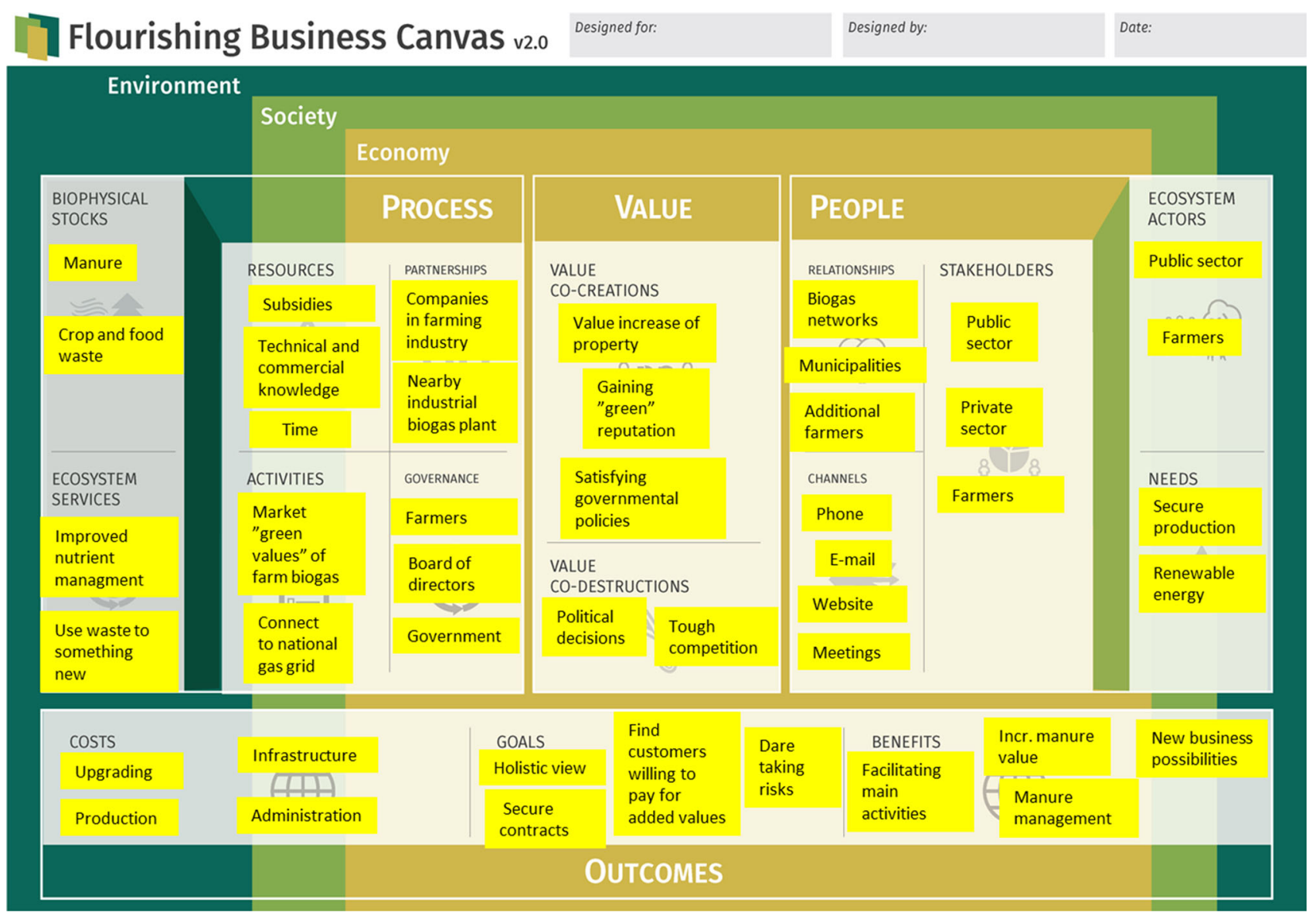

Fig. 5 The "long-distance sales and distribution" BM prototype developed in Workshop 2

1. Increased cooperation and novel partnerships: More cooperation with stakeholders such as local companies, other biogas producers, public actors, and universities. For example, cooperation with car manufacturers and dealers can lead to the promotion of the manufacture and sale of biogas-powered vehicles.

2. Improved marketing/visibility: The creation of a sales/marketing position, so that Sigma and its products are better advertised as locally produced. Renewable fuel as a contributor to sustainable regional development.

3. Sustainability brand creation: Promotion of an organic and sustainable brand in which farm-based biogas production is an important activity.

4. Servitization: Additional services related to the sale and promotion of biogas. More distribution channels, complementary services, and communications on the favourable environmental impact of farm-based biogas production.

The first step of the network-level BM approach is to envision future scenarios as sustainable BM prototypes. External actors who have no prior knowledge of the context and internal actors who are well informed of the context participate in this ideation activity. This heterogeneous mixture of participants promotes a broad perspective and enables idea creation, unrestricted by the current industry logic. At the same time, the mixture can provide further realistic feasibility assessments of the ideas and of the BM prototypes. The second step involves the identification of the network-level BM drivers that correspond to key network-level BM requirements held by various stakeholders, including private-sector firms and publicsector customers (e.g., municipalities). The drivers lie behind the strategies used to create sustainable value via resource efficiency, waste reduction, pollution prevention/ reduction measures, production increase, and the use of clean energy and bio-based fertilizer. The third step is the conceptualization of the network-level BM. At this point, Sigma becomes an integral component in the network as it searches for new business opportunities and formulates strategies for the co-creation of sustainable value for the networked firms and their stakeholders. Finally, the network-level BM can enable a fourth step if stakeholder relationships are managed, such that a stakeholder business 


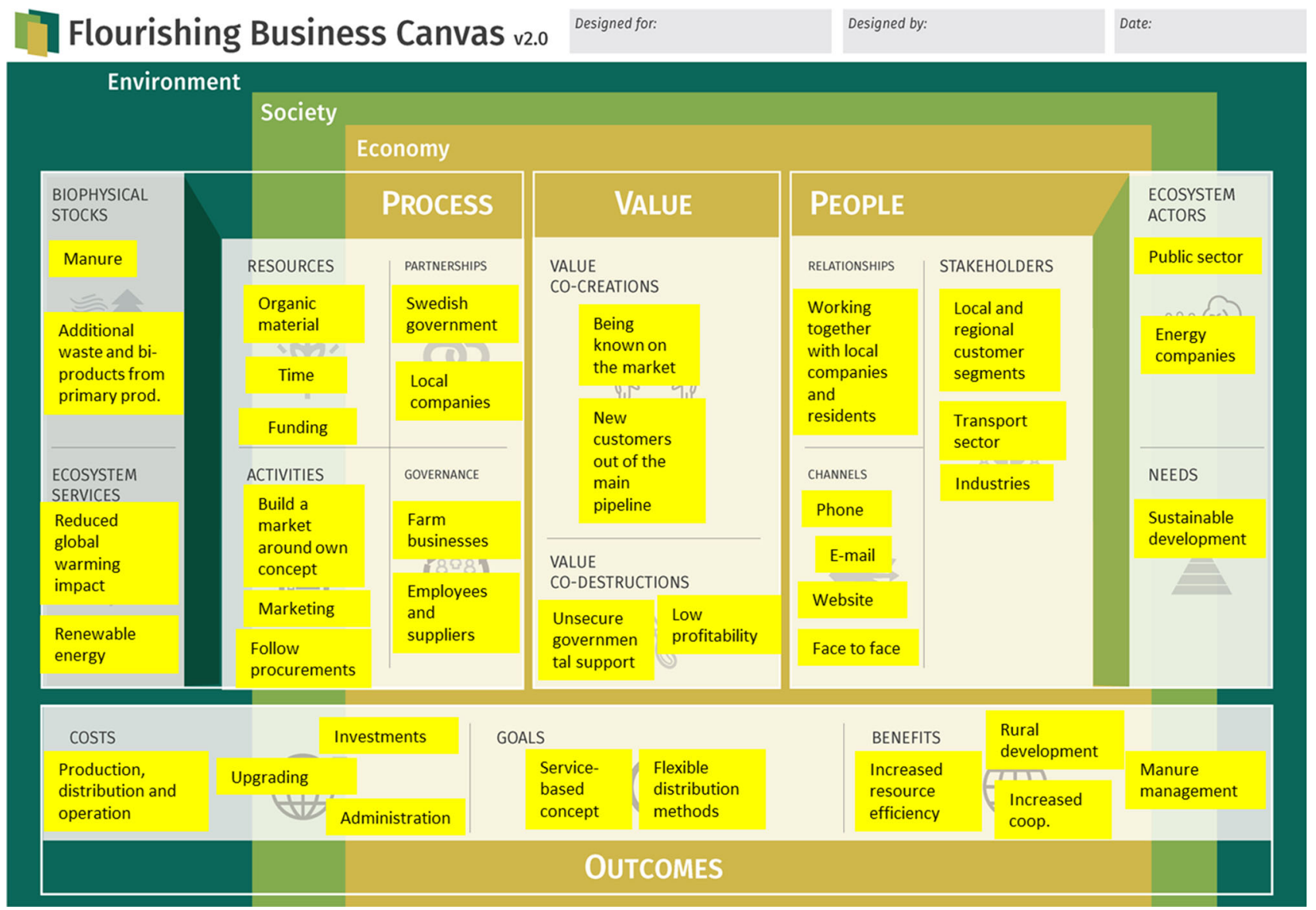

Fig. 6 The "servitization" BM prototype developed in Workshop 2

case for sustainability can be created, developed, and realized.

\section{Discussion}

The creation of, and experimentation with, various BM prototypes at an early stage of business development is an effective way of initiating the work of designing and establishing an actual BM (e.g., Demil and Lecocq 2015). In the last decade, Swedish farmers have begun looking at the possibility that the production of farm-based biogas might generate a new income stream and also contribute to environmental and social sustainability (Lybæk et al. 2013). This new perspective on farm-based biogas production as a stakeholder business case for sustainability suggests farmers and their stakeholders require joint BMs. For this purpose, this paper proposes an approach for developing a network-level BM for sustainability derived from five sustainable BM prototypes (Figs. 2, 3, 4, 5, 6) based on research conducted at a farm network (Sigma) in southern Sweden.
Previous research on farm-based biogas production concludes that the single-firm logic for creating BMs does not provide sufficient knowledge, expertise, resources, and influence for the management of biogas production in the development and establishment stages (Negro et al. 2007; Negro and Hekkert 2008; Wadin Lagerstedt et al. 2017). Our results support this conclusion. In its dependence on individual BMs at the single firm level, Sigma has failed to realize its intended biogas expansion. An alternative aimed at the achievement of the member firms' business goals and the realization of the benefits of farm-based biogas production is a joint network-level BM for sustainability. Success with such a network-level BM, to a large extent, depends on the stakeholder relationships and the formation of networks that share the risks and the rewards (Hellström et al. 2015; Lindgren et al. 2010). Such BM collaboration can complement Sigma's lack of business skills (in marketing, sustainable brand creation, and servitization) and can provide the required financial resources for the needed biogas infrastructure (investment capital for production, upgrading, and distribution of the biogas).

Gauthier and Gilomen (2016) and Schaltegger and Burritt (2015) report that some organizations join 
Table 2 The 215 ideas related to the FBC building blocks

\begin{tabular}{ll}
\hline $\begin{array}{l}\text { FBC building } \\
\text { blocks }\end{array}$ & Ideas \\
\hline Goals & $\begin{array}{c}\text { Expand by selling additional products and knowledge, find investors, reduce greenhouse gas emissions, enter into public } \\
\text { transport partnerships, find customers willing to pay for added value, focus on long-term profitability, use flexible } \\
\text { distribution methods, promote environmental protection, create a sales/marketing position, identify new market } \\
\text { opportunities, merge with the west coast biogas network, take a holistic view, secure more contracts, share benefits, } \\
\text { promote the service-based concept, use biogas for vehicle fuel, create a new image of the company, create a green brand, } \\
\text { become the most sustainable area in Sweden, expand pipelines, promote a strong local spirit, and dare to take risks } \\
\text { Total: } 23\end{array}$
\end{tabular}

Benefits

Total: 23

Bents

Upgraded gas, new business possibilities, renewable energy, clean fuel, social benefits, reduction of methane emissions, creation of different financial strategies, fewer negative effects of climate change, improved resource efficiency, a longterm vision, new supplier market, new skills, job creation, increased cooperation, renewable vehicle fuel, waste management, manure management, zero emissions, more customers, promotion of main farm activities, rural development, sales of knowledge, waste management, and increased manure value

Total: 24

Costs Investments, infrastructure building, communication campaigns, production and distribution, operations, transportation, environmental effects, new employees, potential loss of partnership rights, upgrading, R\&D, new pipelines, salaries, additional production plants, and administration

Total: 15

Ecosystem actors Public sector, energy companies, farmers, private companies, NGOs, the media, and the R\&D sector Total: 7

Needs Renewable energy, waste management, social needs, esteem needs, self-actualization needs, profit, greater cooperation, sustainable development, expansion of markets and resources, secure production, green trend, greater food production, increase in employment, and long-term political decisions

Total: 14

Stakeholders Governing bodies, farmers, environmental groups, the transport sector, the private sector, filling stations, salespeople, recent graduates, environmental representatives, the Board of Directors, new customers, banks, energy companies, industries, companies that control the gas grid, local authorities, cities, green associations, Sigma, companies that own and manage plants, and local and regional customer segments

Total: 21

Relationships With other farmers, municipalities, local companies and residents, universities, private companies, network farmers, other network actors, environmental institutions, biogas networks, vehicle companies, and representatives for the national gas grid

Total: 11

Channels Truck transportation, marketing, face to face meetings, workshops, telephone, e-mail, local focus contacts, meetings, website, and social media

Total: 10

Value co-creations Compliance with governmental policies, long-term solutions, acquired experience, solutions to global warming, environmental sustainability, a "green" reputation, presence in the market, energy enthusiasm of young people, new business opportunities, reduced costs, reduced ecological footprint, profitability, new R\&D, heat, green cities' cooperation, transport of liquid gas, ethanol, and increased property values

Total: 19

Value codestructions

High investments, uncertain market, limited production, political decisions, lack of awareness, no fixed demand, price fluctuation, liability of energy market plan, uncertain governmental support, expensive production costs, few customers, challenging competition, and low profitability

Total: 13

Governance Sigma, network members, employees and suppliers, Board of Directors, farmers, private companies, and governmental bodies

Total: 7

Partnerships Subsidy agencies, partner associates, utility companies, farmers, agri-food companies, new customers not in the main pipeline, the local industrial biogas plant, local companies, energy companies, technological companies, the Swedish national government, municipalities, transport companies, local households, and universities

Total: 15 
Table 2 (continued)

\begin{tabular}{ll}
\hline $\begin{array}{l}\text { FBC building } \\
\text { blocks }\end{array}$ & Ideas \\
\hline Resources & $\begin{array}{l}\text { Manure, farm waste, employee creativity and commitment, investment funds, technical and commercial knowledge, the } \\
\text { distribution grid, organic material, subsidies, household waste, new production plants, company waste, and time } \\
\text { commitments } \\
\text { Total: } 12\end{array}$ \\
Biophysical stocks & $\begin{array}{l}\text { Manure, crop and food waste, farm waste, waste and bi-products from primary production, and organic materials } \\
\text { Total: } 5\end{array}$ \\
& $\begin{array}{l}\text { Upgrades, export construction of joint gas pipes, B2B, other marketing, mixing biogas with natural gas, preparation of } \\
\text { funding applications, production of biogas, biotourism, marketing the "green values" of farm-based biogas production, } \\
\text { pursuit of renewable energy procurements, collection of manure, management of digestates, conversion of biogas to liquid }\end{array}$ \\
& fuel, and creation of a market concept \\
Total: 15 & Reduction of global warming, more renewable energy, conversion of waste to energy, and improved nutrient management \\
Ecosystem & Total: 4
\end{tabular}

collaborative projects more in the expectation that they can meet sustainability challenges than in the expectation that can realize short-term economic benefits. For instance, municipalities have provided support to farm-based biogas production and distribution activities with such motives (Benjaminsson and Benjaminsson 2013: Karlsson et al. 2017). The exploitation of complementary sustainability interests by such key stakeholders is crucial for improving competitiveness (Edgeman and Eskildsen 2014) in the context of farm-based biogas production. For that reason, we argue that the existing and future farm biogas producers need to prioritize the realization of a stakeholder business case for sustainability that addresses the social and environmental needs of local municipalities (Karlsson et al. 2017; Schaltegger et al. 2017). In collaboration with local municipalities, Sigma might develop its biogas infrastructure by investing in new distribution methods (e.g., pipeline-based transport for biogas). This system could provide environmental and social benefits such as reductions in fossil fuel-based road transport, transportation costs, and greenhouse gas emissions. In addition, Sigma might invest in an upgrading facility for converting its raw biogas into biomethane usable as a natural gas replacement in the transport sector.

In line with Seidenstricker et al. (2014) and Upward and Jones (2016), we found that business modelling facilitates the internal and external stakeholder communications required for the initiation of $\mathrm{BM}$ collaboration. Through the visualization of different BM prototypes for future BM scenarios, the internal communications amongst the Sigma members also improved. As a result, the members were empowered to develop a joint vision and a strategy for the biogas expansion (i.e., the need for a network-level BM for sustainability). They also identified the relevant stakeholders (municipalities and local industries) needed to engage in the transition from a single-firm BM to a network-level BM. Sigma used the BM prototypes to explain the reasons for the planned expansion of biogas production to these stakeholders in terms of increased profitability and sustainable production.

The creation and presentation of sustainable BM prototypes using the FBC tool can thus greatly help biogasproducing farmers and their stakeholders to establish successful collaborations. Therefore, we claim that networklevel BMs developed using our approach (Fig. 7) can be the basis for developing farm-based biogas production as a stakeholder business case for sustainability that can improve competitiveness and can lead to new business ventures through the delivery of sustainable outcomes (e.g., mitigated greenhouse gas emissions, job creation, and increased resource efficiency and waste management) (Schaltegger et al. 2017). Furthermore, the visualization and integration of sustainability in a firm's BM with the help of business modelling is an important strategic activity that can change the collaborative mindset of managers and staff (e.g., Stubbs and Cocklin 2008). This change can facilitate the initiation and maintenance of stakeholder collaborations and partnerships that address mutual business interests, leading to improved long-term financial viability. These findings complement the previous results on collaborative business modelling and experimentation in the context of sustainable value co-creation in networks (e.g., Evans et al. 2017).

\section{Theoretical and managerial contributions}

The main contribution of this study is its response to the call by Schaltegger et al. (2017) for the use of the theoretical concept of the stakeholder business case for sustainability in empirical research. Our study describes a 


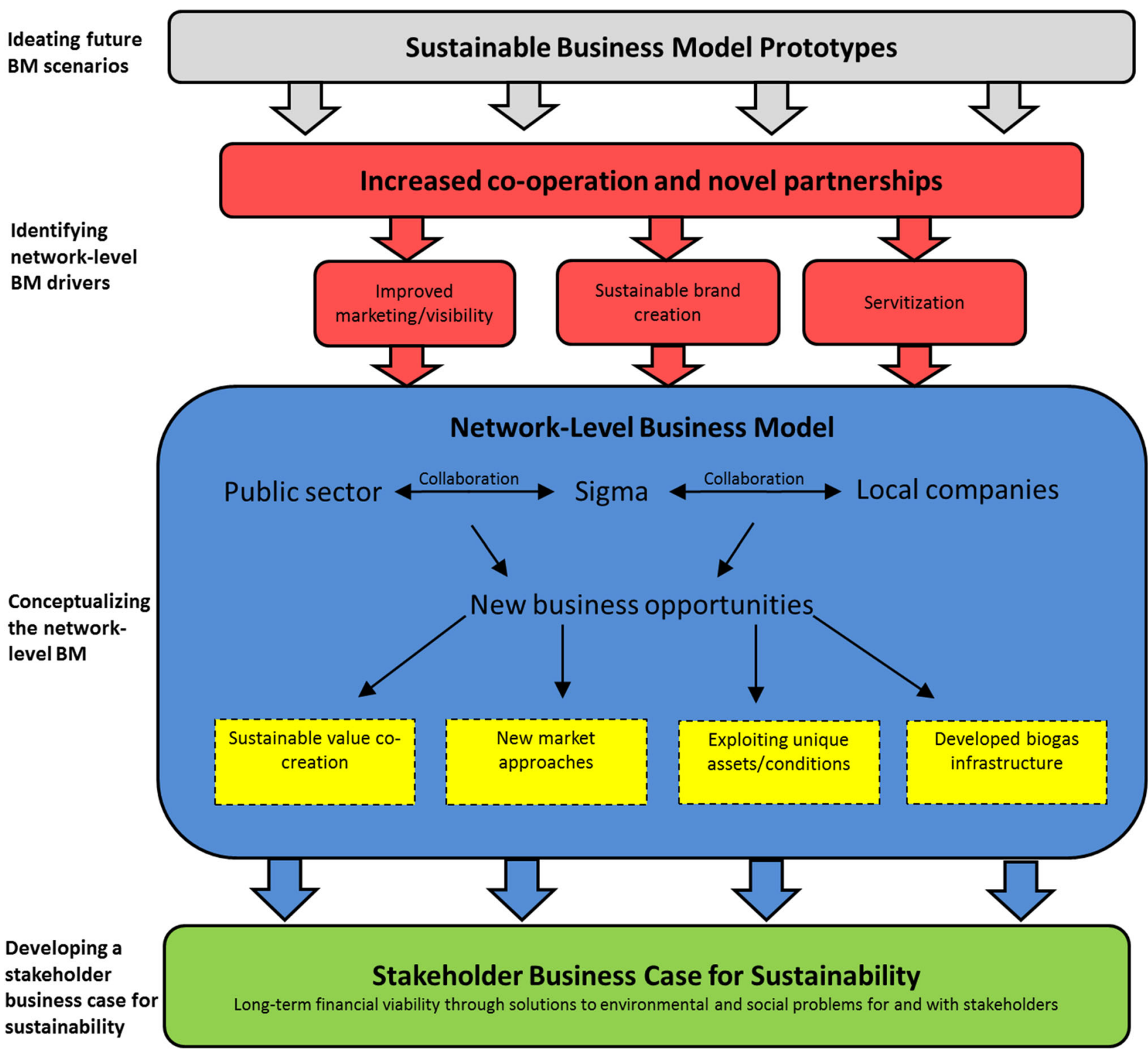

Fig. 7 The network-level BM approach illustrates how sustainable BM prototypes can be used to develop a network-level BM that can realize farm-based biogas production as a stakeholder business case for sustainability

practical approach for the development and potential realization of a network-level $\mathrm{BM}$ in a network of individual firms. Using business modelling to create BM prototypes based on the sixteen FBC building blocks, we describe an approach for developing a network-level BM for sustainability. This approach, with its clear focus on sustainable value creation and stakeholder management, can be used as a template for developing other networklevel BMs that can create stakeholder business cases for sustainability in different contexts.

By forming a "community of practice" based on our network-level BM approach, firm owners and managers can work with researchers, consultants, and other stakeholders to identify ways to advance environmental, economic, and social sustainability through which longterm financial viability can be improved. Our findings complement the previous sustainable BM research by showing how firms and stakeholders can benefit both collectively and individually from collaborative business modelling and experimentation (Bocken et al. 2013; Evans et al. 2017; Joyce and Paquin 2016). Furthermore, we show that the emerging design focus in sustainable BM research (Geissdoerfer et al. 2016; Lehmann et al. 2015) can be facilitated by business modelling and analyzed using BM prototypes (Demil and Lecocq 2015).

From a practical perspective, our results can be used to identify and visualize the drivers of collaborative networks and partnerships, the relevant stakeholders, and the new 
business opportunities associated with a network-level BM for sustainability. We found that the development of a network-level BM for sustainability and a stakeholder business case for sustainability in the biogas-producing activity is mainly driven by sustainability-oriented branding and marketing, stakeholder involvement, and changes in the competitive environment. With these results, our study complements the research on antecedents and drivers of BM renewal and adaptation (Foss and Saebi, 2017; Saebi et al. 2017) by showing that sustainability pioneers such as biogas-producing farmers require a holistic approach. Such an approach includes internal and external activities at the firm level if network-level BMs for sustainability are to support long-term financial viability.

\section{Suggestions for further research}

The development of a network-level BM for sustainability requires that a number of dedicated firm owners and public actors collaborate as they try to achieve long-term goals. There are several research opportunities in the examination of such collaborative networks.

Future research may examine our network-level BM approach in other industrial contexts and with other firm networks and stakeholders. For example, empirical studies of the use of the approach in other business groups would be fruitful. Such research might also address the roles and input of various stakeholders (e.g., local authorities, customers, external stakeholders, and researchers) when a network-level BM is created and implemented. In the development of a network-level BM and a stakeholder business case for sustainability in practice, researchers might also investigate the moderating effects of, for example, ethical motivations, organizational values, and leadership characteristics that Schaltegger and Burritt (2015) describe.

We also suggest that researchers further examine the specific industry context of our study. They might take an empirical approach as they study the key actors in networklevel BMs for farm-based biogas production. For example, which roles do the various actors play? Which governance rules and power distribution schemes favour the creation and development of sustainable network-level BMs and the subsequent realization of farm-based biogas as a stakeholder business case for sustainability?

The Sigma case also offers further research opportunities. Our study covers the conceptualization of the networklevel BM intended to help solve Sigma's financial problems. The next step for Sigma and its stakeholders is to implement the network-level BM. There is much to be learned about the theoretical and practical issues that arise when a network-level BM is implemented. Therefore, we recommend that future research investigates the network- level BM implementation and evaluates its results (economic, environmental, and social).

\section{Conclusions}

This study offers a new, collaborative approach to the development of network-level BMs for sustainability in farm-based biogas production. In its examination of the network concept in the practice of sustainable BM development, the study concludes that collaborative business modelling using the FBC can be used to progress from a narrow firm-level focus to a broad network-level focus. Furthermore, this study shows that business modelling is an effective way to facilitate the work of turning ideas for change into BMs, and for understanding the potential benefits of network-level BMs. A network-level BM (versus the single-firm BM) for sustainability can result in more customers, the expansion of business activities, an increase in sustainable value creation, and higher financial returns. Thus, we conclude that sustainability can be both a trigger for, and a result of, collaborative BM development.

The perspectives and interests of the various stakeholders in networked biogas production systems may be rather different. Such diversity can pose challenges to their collaborative efforts. However, the need for change, whatever its reason, can motivate various actors to unite as they formulate and try to achieve common goals. For Sigma, the poor profitability of the biogas activity motivated its need for change. The challenge, therefore, was to create and develop conditions for improved financial viability. A network-level BM developed for and with stakeholders could create such conditions and generate positive synergistic outcomes. These (possible) outcomes included sustainable value co-creation and greater competitiveness in the long term.

The traditional BMs frequently centre on specific areas (e.g., key activities or distribution channels). However, we found that sustainable BMs in farm-based biogas production are quite complex and require a holistic approach that recognizes the importance of environmental and social benefits as contributors to financial viability. As we describe in the discussion section, this approach depends on the development of a network-level BM for sustainability that includes committed firm owners, supportive local administrations, and other stakeholders who are willing to make long-term investments as they share the risks and rewards. Such network-level BMs form the foundation for the development and realization of a stakeholder business case for sustainability in which farmers and other stakeholders jointly, through the solution of environmental and social problems, create and promote conditions for the long-term financial profitability of farm-based biogas production. 
Finally, we conclude that effective development of a network-level BM for sustainability and the realization of a stakeholder business case for sustainability depend on the establishment of a mutually beneficial collaboration between the network actors and the other stakeholders from the very initiation of the process. In some instances, this group of actors may include regional and local municipalities. An innovative, risky, and expensive endeavour that can have positive social and environmental effects (such as farm-based biogas production) requires the commitment of a diverse group of stakeholders. Because of the many, albeit often intangible, sustainability benefits of such endeavours, we conclude that it is worth investigating farm-based biogas production in a broader contest using our practical approach for developing a network-level BM and stakeholder business case for sustainability.

Acknowledgements This study was partly funded by the Biogas 2020 project in the EU-Interreg ÖKS programme. The authors thank the anonymous reviewers for their helpful advice and comments.

\section{Compliance with ethical standards}

Conflict of interest The authors declare no conflicts of interest.

Open Access This article is distributed under the terms of the Creative Commons Attribution 4.0 International License (http://creative commons.org/licenses/by/4.0/), which permits unrestricted use, distribution, and reproduction in any medium, provided you give appropriate credit to the original author(s) and the source, provide a link to the Creative Commons license, and indicate if changes were made.

\section{References}

Abdelkafi N, Täuscher K (2016) Business models for sustainability from a system dynamics perspective. Org Environ 29(1):74-96

Allee V (2011) Value networks and the true nature of collaboration. Value Networks-Verna Allee Associates, Pleasant Hill

Amer SB, Bolwig S (2013) Innovations in Nordic value chains for biogas: Denmark (Maabjerg BioEnergy) case study. TOP-NEST, Project number RD 2011-42. Nordic Energy Research

Amit R, Zott C (2001) Value creation in e-business. Strateg Manag J 22(6/7):493-520

Amit R, Zott C (2012) Creating value through BM innovation. MIT Sloan Manag Rev 53(3):41-49

Araujo L, Dubois A, Gadde L-E (2003) The multiple boundaries of the firm. J Manag Stud 40(5):1255-1277

Aversa P, Haefliger S, Rossi A, Baden-Fuller C (2015) From business model to business modelling: modularity and manipulation. Business models and modelling. Emerald Group Publishing Limited, Bingley, pp 151-185

Äyväri A, Jyrämä A (2017) Rethinking value proposition tools for living labs. J Service Theor Pract 27(5):1024-1039

Bankvall L, Dubois A, Lind F (2017) Conceptualizing business models in industrial networks. Ind Market Manag 60:196-203

Benjaminsson J, Benjaminsson G (2013) Samverkanskoncept för biogasproduktion inom lantbruket- minimering av risker i realiserade projekt [Collaboration concepts for biogas production in agriculture-minimization of risks in realized projects]. Gasefuels AB and Biogas Öst

Bergh A (2013) Factors for success in Swedish biogas—a study based on the Swedish agricultural sector. Degree Project, No. 803, Department of Economics. Swedish University of Agricultural Sciences, Uppsala, Sweden

Bergold J, Thomas S (2012) Participatory research methods: a methodological approach in motion. Hist Soc Res 37(4):191-222

Bessant J, Francis J (1999) Using learning networks to help improve manufacturing competitiveness. Technovation 19(6/7):373-381

Bocken N, Short S, Rana P, Evans S (2013) A value mapping tool for sustainable business modelling. Corp Govern 13(5):482-497

Bocken N, Short S, Rana P, Evans S (2014) A literature and practice review to develop sustainable business model archetypes. J Clean Prod 65:42-56

Boons F, Lüdeke-Freund F (2013) Business models for sustainable innovation: state-of-the-art and steps towards a research agenda. J Clean Prod 45:9-19

Boulamanti AK, Maglio SD, Giuntoli J, Agostini A (2013) Influence of different practices of biogas sustainability. Biomass Bioenerg 53:149-161

Chesbrough H, Rosenbloom RS (2002) The role of the business model in capturing value from innovation: evidence from Xerox Corporation's technology spinoff companies. Ind Corp Change 11(3):529-555

Coughlan P, Coghlan D (2002) Action research for operations management. Int J Oper Prod Man 22(2):220-240

Creswell JW, Creswell JD (2017) Research design: qualitative, quantitative, and mixed methods approaches. Sage Publications, Thousand Oaks

Demil B, Lecocq X (2010) Business model evolution: in search of dynamic consistency. Long Range Plan 43(2-3):227-246

Demil B, Lecocq X (2015) Crafting an innovative business model in an established company: the role of artifacts. In: Baden-Fuller C, Mangematin V (eds) Business models and modelling. Emerald Group Publishing Limited, Bingley, pp 31-58

Edgeman R, Eskildsen J (2014) Modeling and assessing sustainable enterprise excellence. Bus Strateg Environ 23(3):173-187

Elkington R, Upward A (2016) Leadership as enabling function for flourishing by design. J Glob Responsib 7(1):126-144

Ericsson K, Nikoleris A, Nilsson LJ (2013) The biogas value chains in the Swedish region of Skåne. TOP-NEST, Project number RD 2011-42. Nordic Energy Research

European Commission (2011) Communication from the Commission to the European Parliament, the Council, the European Economic and Social Committee and the Committee of the Regions, Horizon 2020-The Framework Programme for Research and Innovation

Evans S, Vladimirova D, Holgado M, Van Fossen K, Yang M, Silva EA, Barlow CY (2017) Business model innovation for sustainability: towards a unified perspective for creation of sustainable business models. Bus Strateg Environ 26:597-608

Fallde M, Eklund M (2015) Towards a sustainable socio-technical system of biogas for transport. The case of the City of Linköping in Sweden. J Clean Prod 98:17-28

Foss NJ, Saebi T (2017) Fifteen years of research on business model innovation: how far have we come, and where should we go? J Manag 43(1):200-227

Frankenberger K, Weiblen T, Csik M, Gassmann O (2013) The 4Iframework of business model innovation: a structured view on process phases and challenges. Int J Prod Dev 18(3/4):249-273

Freytag PV, Clarke AH (2012) Understanding change in industry and business models-On the changing role of advertising agencies. IMP Conference, Rome

Gauthier C, Gilomen B (2016) Business models for sustainability: energy efficiency in urban districts. Org Environ 29(1):124-144 
Geissdoerfer M, Bocken NM, Hultink EJ (2016) Design thinking to enhance the sustainable business modelling process-A workshop based on a value mapping process. J Clean Prod 135:1218-1232

Goddard W, Melville S (2004) Research methodology: an introduction, 2nd edn. Blackwell Publishing, Hoboken

Graham H, Hill K, Holland T, Pool S (2015) When the workshop is working - the role of artists in collaborative research with young people and communities. Qual Res J 15(4):404-415

Hall J, Wagner M (2012) Integrating sustainability into firms' processes: performance effects and the moderating role of business models and innovation. Bus Strateg Environ 21(3):183-196

Hanshaw N, Osterwalder A (2015) The business model canvas: why and how organizations around the world adopt it. A field report. Strategyzer. Available at: https://s3.amazonaws.com/strategyzr/ assets/research_report.pdf

Hellström M, Tsvetkova A, Gustafsson M, Wikström K (2015) Collaboration mechanisms for business models in distributed energy ecosystems. J Clean Prod 102:226-236

Huttunen S, Manninen K, Leskinen P (2014) Combining biogas LCA reviews with stakeholder interviews to analyse life cycle impacts at a practical level. J Clean Prod 80:5-16

Johnson MW, Suskewicz J (2009) How to jump-start the clean tech economy. Harvard Bus Rev. 87(11):52-60

Joyce A, Paquin R (2016) The triple layered business model canvas: a tool to design more sustainable business models. J Clean Prod 135(1):1474-1486

Karlsson N, Halila F, Mattsson M, Hoveskog M (2017) Success factors for agricultural biogas production in Sweden: a case study of business model innovation. J Clean Prod 142(4):2925-2934

Karlsson N, Hoveskog M, Halila F, Mattsson M (2018) Early phases of the business model innovation process for sustainability: addressing the status quo of a Swedish biogas-producing farm cooperative. J Clean Prod 172:2759-2772

Kreiss C, Nasr N, Kashmanian R (2016) Making the business case for sustainability: how to account for intangible benefits-a case study approach. Environ Qual Manag 26(1):5-24

Lantz M (2013) Biogas in Sweden-opportunities and challenges from a systems perspective. Doctoral thesis in Engineering Environmental and Energy System Studies, Lund University, Sweden

Lehmann M, Bocken NMP, Steingrímsson JG, Evans S (2015) Incorporating design thinking into sustainable business modelling. Sust Des Manuf 2015:297-316

Lindgren P, Taran Y, Boer H (2010) From single firm to networkbased business model innovation. Int $\mathbf{J}$ Entrepreneurship Innov Manag 12(2):122-137

Lüdeke-Freund F (2010) Towards a conceptual framework of business models for sustainability. In: Proceedings of the Knowledge Collaboration \& Learning for Sustainable Innovation, Conference October

Lüdeke-Freund F, Dembek K (2017) Sustainable business model research and practice: emerging field or passing fancy? J Clean Prod 168:1668-1678

Lybæk R, Christensen TB, Kjær T (2013) Governing innovation for sustainable development in the Danish biogas sector-a historical overview and analysis of innovation. Sustain Dev 21:171-182

Martin M (2015) Potential of biogas expansion in Sweden: identifying the gap between potential studies and producer perspectives. Biofuels. https://doi.org/10.1080/17597269.2015.1090769

Middel R, Coghlan D, Coughlan P, Brennan L, McNichols T (2006) Action research in collaborative improvement. Int $\mathrm{J}$ Technol Manag 33(1):67-91

Möller K, Rajala A, Svahn S (2005) Strategic business nets-their type and management. J Bus Res 58:1274-1284
Morris M, Schindehutte M, Allen J (2005) The entrepreneur's business model: toward a unified perspective. J Bus Res 58:726-735

Negro SO, Hekkert MP (2008) Explaining the success of emerging technologies by innovation system functioning: the case of biomass digestion in Germany. Technol Anal Strateg 20(4):465-482

Negro SO, Hekkert MP, Smits RE (2007) Explaining the failure of the Dutch innovation system for biomass digestion-a functional analysis. Energ Policy 35(2):925-938

Österle H, Fleisch E, Alt R (2001) Business networking: shaping collaboration between enterprises, 2nd edn. Springer Verlag, Berlin

Osterwalder A, Pigneur Y (2010) Business model canvas. Selfpublished

Osterwalder A, Pigneur Y, Tucci CL (2005) Clarifying business models: origins, present, and future of the concept. Commun Assoc Inform Syst 16:1-25

Osterwalder A, Pigneur Y, Bernarda G, Smith A (2014) Value proposition design: How to create products and services customers want. Wiley, Hoboken

Palo T, Tähtinen J (2013) Networked business model development for emerging technology-based services. Ind Market Manag 42:773-782

Rauter R, Jonker J, Baumgartner RJ (2017) Going one's own way: drivers in developing business models for sustainability. J Clean Prod 140:144154

Robson C, McCartan K (2015) Real world research, 4th edn. Wiley, London

Rohrbeck R, Konnertz L, Knab S (2013) Collaborative business modelling for systemic and sustainability innovations. Int $\mathrm{J}$ Technol Manag 63(1-2):4-23

Rowlands BH (2005) Grounded in practice: using interpretive research to build theory. Electron $\mathrm{J}$ Business Res Methods $3(1): 81-92$

Saebi T, Lien L, Foss NJ (2017) What drives business model adaptation? The impact of opportunities, threats and strategic orientation. Long Range Plan 50(5):567-581

Schaltegger S, Burritt R (2015) Business cases and corporate engagement with sustainability: differentiating ethical motivations. J Bus Ethics 147:1-19

Schaltegger S, Lüdeke-Freund F, Hansen E (2012) Business cases for sustainability: the role of business model innovation for corporate sustainability. Int J Innov Sust Dev 6(2):95-119

Schaltegger S, Hansen E, Lüdeke-Freund F (2016a) Business models for sustainability: origins, present research, and future avenues. Org Environ 29(1):3-10

Schaltegger S, Lüdeke-Freund F, Hansen E (2016b) Business models for sustainability - a co-evolutionary analysis of sustainable entrepreneurship, innovation and transformation. Org Environ 29(3):264-289

Schaltegger S, Hörisch J, Freeman RE (2017) Business cases for sustainability: a stakeholder theory perspective. Org Environ, pp 1-22

Seidenstricker S, Scheuerleb S, Linder C (2014) Business model prototyping - using the morphological analysis to develop new business models. Proc Soc Behav 148:102-109

Shani AB, Pasmore WA (1985) Organization inquiry: towards a new model of the action research process. In: Warrick DD (ed) Contemporary organization development: current thinking and applications. Scott, Foresman, Glenview

Shani AB, Coghlan D, Cirella S (2012) Action research and collaborative management research: more than meets the eye? Int J Action Res 8(1):45-67

Stubbs W, Cocklin C (2008) Conceptualizing a sustainability business model. Org Environ 21(2):103-127 
Susman GI, Evered RD (1978) An assessment of the scientific merits of action research. Adm Sci Q 23(4):582-603

Teece D (2010) Business models, business strategy and innovation. Long Range Plan 43(2-3):172-194

Upward A, Davies SN (2018) Realizing the flourishing imperative. In: Wunder $\mathrm{T}$ (ed) Rethinking strategic management: competing through a sustainability mindset. Springer International, Heidelberg

Upward A, Jones PH (2016) An ontology for strongly sustainable business models: defining an enterprise framework compatible with natural and social science. Org Environ 29(1):97-123

Vernay A-L, Mulder KF, Manon Kamp L, de Bruijn H (2013) Exploring the socio-technical dynamics of systems integration- the case of sewage gas for transport in Stockholm,Sweden. J Clean Prod 44:190-199

Wadin Lagerstedt J, Ahlgren K, Bengtsson L (2017) Joint business model innovation for sustainable transformation of industries-a large multinational utility in alliance with a small solar energy company. J Clean Prod 160:139-150

Zott C, Amit R (2010) Business model design: an activity system perspective. Long Range Plan 43(2/3):216-226

Zott C, Amit R, Massa L (2011) The business model: recent developments and future research. J Manag 37(4):1019-1042 